\title{
Applying Immune Instincts and Maternal Intelligence from Comparative Microbiology to COVID-19
}

\author{
Nevio Cimolai ${ }^{1,2}$ (D) \\ Accepted: 4 November 2020 / Published online: 9 November 2020 \\ (C) Springer Nature Switzerland AG 2020
}

\begin{abstract}
New data specific to COVID-19 are emerging quickly on key issues of immunity and prevention, but past research in coronavirology and for other human pathogens (e.g., Mycoplasma pneumoniae) has been available and of great relevance. Considerable study of endemic human coronaviruses has shown that neutralizing antibody correlates with protection, but effective clinical protection is variable for subsequent virus exposure. Animal coronavirus research has emphasized the importance of local mucosal protection (especially IgA) and systemic responses. Animal model and human post-infection studies for SARS-CoV and MERS-CoV are largely corroborative. Whether for passive therapeutic strategies or vaccination, these findings provide a template for COVID-19. Many approaches to vaccination have emerged, and there may be more than one vaccine that will be applied, but individualized obstacles and concerns for administration, efficacy, and safety are inevitable. Regardless of safeguards or promises that may be understood from laboratory or vertebrate experiments, observations from large-scale human trials will ultimately prove to shape the medical future. Focus on common mucosal immunity can be underrated, and equally or more, focus on lactogenic immunity may be underestimated. In understanding both passive immunity and protection, the body is already primed to educate us with decisions of what constitutes protection and harm. This review provides key insights that drive hypotheses into how the instinct of immunity and the intelligence of the maternal component of the common mucosal immune system has already guided us and may continue to do so effectively into a bright and safe future.
\end{abstract}

Keywords Coronavirus · Infection $\cdot$ Immunity $\cdot$ Mucosa $\cdot$ Lactation

\section{Introduction}

The magnitude of the COVID-19 pandemic has pushed the scientific community towards expeditiously creating novel vaccines, and many have progressed through various stages of development $[1,2]$. The speed of progression and the inherent desire to succeed have raised some controversy [3, 4]. Nevertheless, remaining fundamental issues are whether an effective timely vaccine can be produced and whether safety acceptability is met. There is considerable science that reflects on many issues of relevant immune responses in both coronavirology and other infection models. Vaccines are often assessed through simplified vaccination and

This article is part of the Topical Collection on COVID-19

Nevio Cimolai

ncimolai@mail.ubc.ca

1 Faculty of Medicine, The University of British Columbia, Vancouver, BC, Canada

2 Children's and Women's Health Centre of British Columbia, 4480 Oak Street, Vancouver, BC V6H3V4, Canada challenge (experimental or natural infection) protocols. Yet, the immune response after natural infection provides considerable insight that should be considered before vaccines are produced and trialed. A selection of these insights are highlighted herein. The potential contributions of mucosal immunology and the adaptive maternal immune response are discussed as a prelude to how SARS-CoV-2-related immunity can be better understood. It is thereafter hypothesized that lactogenic immunity will model key immune responses that should be sought after vaccination or natural infection.

\section{Comparative Microbiology Provides Insight into COVID-19}

\section{Mycoplasma pneumoniae as the Non-viral Model for COVID-19 Vaccinology?}

M. pneumoniae is pleomorphic, cell wall-less, and among the smallest of bacteria. The DNA genome is approximately $816 \mathrm{kB}$. Coronaviruses are among the largest RNA viruses 
and genomes vary $\sim 26-31 \mathrm{kB}$. M. pneumoniae is predominantly a respiratory pathogen but has potential to cause a variety of pathological systemic and immune responses. There are many lessons to be learned from $M$. pneumoniae experimentation that bear relevance to coronavirology and to SARSCoV-2 research. It is remarkable how the problems emerging with SARS-CoV-2 vaccine development pattern those previously demonstrated in $M$. pneumoniae studies of past.

Several animal models emerged for $M$. pneumoniae especially hamster, murine, and simian versions. The Golden Syrian hamster model was most utilized for M. pneumoniae, and this has now been proven useful for SARS-CoV and SARS-CoV-2 [5-7]. Vaccine studies in both animal models and humans emerged decades ago for the bacterium. Initially, it was proposed that passive immunity with polyclonal antisera of homologous or heterogeneous sources could protect from live bacterial challenge, but that protection was variable $[8,9]$. Although the maximal time for lung disease in hamsters after initial challenge peaked at 10-14 days analogous to humans, second infections were accompanied by an accentuated lung pathology within 3-5 days [10]. The latter however was not unique to re-infections. Further studies found early hyperaccentuated pulmonary pathological responses in the context of second challenges with heat-killed bacterium, cell-free extracts, primary immunization with inactivated bacterium or component vaccination, and avirulent protein-deficient mutants [10-13]. Fernald and colleagues found that the majority of immune cellular reactivity in the recall accentuated responses was considerably less represented by antibody-producing lymphocytes [14]. As well as recruiting non-antibody-producing white blood cells, pathology was also accompanied by perivascular immune infiltrates $[11,14]$. Confusing in these studies was that although reinfected hamsters had early pathology, their lungs were either deplete of or had markedly reduced late bacterial numbers [10]. Thus, when animals were examined after 10-14 days, when once infected animals had maximal pathology, it was thought that protection had been afforded [15]. An understanding of the early accentuated response may not be observed if it occurred so early. Accentuated pathology was not seen after infectious challenge of animals that were given hyperimmune polyclonal antibody [9]. Attempts with oral vaccination with killed whole bacterium with or without adjuvants were associated with less histopathology and no recall events, but did not reduce bacterium in lung tissue [10, 16, 17]. It was not resolved as to whether the latter observations were due to protection or immunological tolerance. No such enhanced pathology was observed in early studies with primates [18, 19]. There were several methods for scoring lung pathology in hamster models, but the more sophisticated were necessary to reliably show differences when using small numbers of animals [20]. Such scoring was also used in the study of SARS-CoV lung pathology [21]. Others have recently proposed from murine models that induced $\mathrm{IgG}$ can prevent lung disease, but IgA is more important for protection in the upper respiratory tract [22]. Both $M$. pneumoniae-associated polysaccharides and glycolipids were also assessed as immunogens; a polysaccharide fraction was said to protect hamsters in subsequent challenge, but early accentuated responses were not looked for [23].

Many of the above findings were a prelude to what has more contemporaneously been designated "antibody-mediated enhancement" (ADE) [24]. In animal models for SARS$\mathrm{CoV}$, early accentuated disease after live post-vaccination challenge proved to represent a significant obstacle $[21,25$, 26]. Wan and colleagues have recently contemplated on the mechanisms for the latter [27]. Such phenomena were also found in other coronavirus studies and in other vaccine studies [28-32].

Experimental human infection was easily achieved, although more severe disease was apparent when the strain was low passage [33]. In a different era, vaccine studies (both pediatric and adult) evolved very quickly and after inaugural potency studies were conducted in animal models [34-43]. Methods of inactivation proved to affect vaccine efficacy, and thus formalin-inactivated whole-cell vaccine was most often used [41]. One study found that volunteers who responded less to the vaccine subsequently developed worse disease after challenge [35]. The latter was thought initially to represent a hypersensitization to the vaccine but was often carried forward later as a possible human equivalent of ADE. Regardless, most subsequent formalin-inactivated vaccine trials in thousands of subjects did not show similar accentuated reactivity to subsequent infection [41]. Most vaccine trials showed protection against infection but with mild to moderate efficacy. One large-scale study was a prominent exception, however, and bronchitis and pneumonia protection were estimated at $87 \%$ and $66 \%$ respectively [41]. With a formalin-inactivated pentavalent vaccine which included $M$. pneumoniae, neutralizing antibody to the bacterium reached titers of 1:40 [44]. There was a dose-response effect, but the potential for the virus components as immune boosters for $M$. pneumoniae was not determined. With such results, these vaccines did not become mainstream even for high-risk groups. In the current era, such vaccine efficacy would clearly rival the efficacy of current influenza vaccines which have been widely adopted.

One of the most pressing questions, however, was whether there could be a serological or similar marker that could predict protection after natural infection or vaccine success. In the field of virology, virus neutralization was often being used as that marker. In mycoplasmology, neutralization studies took on various names [45]. The latter included growth inhibition (GI), metabolic inhibition (MI), tetrazolium reduction inhibition (TRI), plaque reduction, inhibition microscopy, and mycoplasmacidal activity. In the hamster model, GI, MI, or 
TRI antibodies appeared to correlate with protection, although some studies were complicated by lack of consideration for hyperaccentuated early responses $[34,35]$. Other antibody measures such as complement fixation or indirect hemagglutination were not good predictors [34]. Furthermore, protection was also correlated with the quality of anamnestic response after infection challenge post-vaccination. In the simian model, small trials found that MI antibodies did not correlate with protection after formalin-inactivated vaccine [18]. Assessments in human natural infections or volunteer vaccine studies also examined serological markers for protection [35-43]. The existence of naturally acquired GI antibody correlated with some protection in volunteers [46]. Such protection was said to correlate better with this neutralizing antibody compared to complement-fixation antibodies [37]. Formalininactivated vaccine induced small increments in GI antibodies, and it necessitated multiple dosing [35, 39]. Nevertheless, it appeared that such antibody status correlated with protection $[35,37,41]$. Some found that this antibody could last for nearly 2 years [41]. There was a better MI antibody response post-vaccination if previously existing such antibody was naturally had $[38,39]$. MI antibodies could not be demonstrated by some for sputa or nasal washes after formalin-inactivated vaccine [38]. Others found respiratory IgA after vaccination correlated better with protection than the presence of serum antibody [40]. For some nearly 8000 volunteers, formalin-inactivated parenteral vaccination gave protection for pneumonia, but not bronchitis; no hyperreactive recall responses were apparent [43].

One of the underrated studies was that of Katsura and colleagues [47]. In a murine model, animals were infected intranasally. Enzyme immunoassay immunoglobulin G persisted for nearly a year in both infected infant and adult mice. Protection from rechallenge was proposed but assessed only with quantitative bacteriology rather than lung histopathology. Maternal mice afforded protection through feeding their offspring. Newborn mice from uninfected dams were also protected by feeding from previously infected dams, but newborns from infected mice were not protected when fed from uninfected dams. Protection was deferred to $\operatorname{IgG}$ rather than IgA, but the studies nevertheless were important in potentially opening relevant avenues. That is, corroboration of such findings could therefore help define protective immunity and target more critical epitopes. A repeat of such studies would relook at whether newborn animals with lactogenic protection are capable of developing early recall lung pathology and furthermore would also relook at correlating protective antibodies with further analyses of systemic versus mucosal immunoglobulins. There is promise since some mucosal antiMycoplasma pneumoniae sIgA antibodies may be found in human breast milk which vary from systemic antibodies [48, 49].

\section{Key Applications from Animal Coronavirology}

There are several animal coronaviruses that have been considerably studied in regard to mucosal and passive immunity, and the following key findings bear relevance.

\section{Porcine Transmissible Gastroenteritis Virus and Respiratory Coronavirus}

Infections from these pathogens present with varying enteric and respiratory illnesses. This discussion uses transmissible gastroenteritis virus (TGEV) as the model for these two viruses albeit they bear some antigenic relatedness. In a TGEV infection model, intestinal neutralizing IgA develops, and there is progressive increase in serum neutralizing antibody [50-52]. Wild-type virus protected both gilts and their offspring $[50,53]$. Colostrum could neutralize live virus and prevent challenge infection. Wild-type infection produced more neutralizing IgA than IgG, and IgA presence correlated better with protection. In colostrum, neutralizing antibody included IgG, IgA, and IgM [54]. Post-challenge colostral IgA had greater neutralizing capability than IgG and IgM [55]. The greater the infectious inoculum for sows, the higher the neutralizing capacity of both serum and milk [56]. The higher the neutralizing capacity, the greater the protection for piglets. With oral infection, IgG was prominent in serum and lung, but IgA was prominent in intestinal fluid; neutralizing antibody lasted for months. In the colostrum-milk transition, there was a decrease in $\operatorname{IgG}$ while $\operatorname{IgA}$ increased proportionately [57]. Secretory $\operatorname{IgA}$ was found to enhance virus cellular attachment, but the subsequent neutralization of virus prevented entrance [58]. Intramammary inoculation of live TGEV protected offspring via milk more than parenteral immunization [59]. Attenuated live TGEV could induce high neutralizing titers in milk [60]. Infectious challenge after the latter was followed by an anamnestic neutralizing response. Vaccination with attenuated or non-attenuated live vaccines led to neutralizing lactogenic antibody which increased survival of piglets after wild-type challenge [61]. It was suggested that the gastrointestinal-mammary linkage was more important in stimulating lactogenic $\operatorname{IgA}$ than the respiratory-mammary linkage [57].

Specific epitopes on the spike (S) protein carried more potential for inducing protective antibody than $\mathrm{N}$ or M proteins, and it was proposed that anti-S immune responses were responsible for lactogenic immunity [52]. Unique studies with Salmonella-expressed viral spike protein, Lactococcusexpressed viral spike protein, and recombinant IgA showed that virus neutralization could be achieved [62-64]. Of note, $5 \%$ of human milk samples contained IgA to TGEV [65]. Transgenic mice which are created to express TGEV-neutralizing monoclonal antibody can facilitate lactogenic responses [66]. 
Cross-protection occurs for TGEV and porcine respiratory coronavirus (PRCV) [53, 57, 67-69]. The mechanisms of protection of offspring are again related to $\operatorname{IgA}$ production in colostrum and milk. Milk-derived neutralizing antibody could map $\mathrm{S}$ protein domains that were likely more important than others [68]. Delivery route of viral antigen has bearing on the more prominent mucosal site for protection [70]. Saif and colleagues reviewed lactogenic immunity in these model systems [70, 71].

\section{Porcine Epidemic Diarrhea Virus}

Among many porcine coronaviruses, porcine epidemic diarrhea virus (PEDV) causes epidemic enteritis. Wild-type virus infection confers protection and did so more than an attenuated strain [72]. Infection induced production of IgA which correlated with intestinal protection. Serum antibody develops alongside mucosal production proportionately. Neutralizing antibody to spike protein could be mapped [73]. Neutralizing antibody was found to be higher in colostrum and milk than serum and was more likely to include IgA [73]. Such neutralizing antibodies have the tendency to extinguish slowly after parturition [73]. Lactogenic immunity was ascribed to the common mucosal immune system and defined as the "gut-mammary axis" [71, 74]. Repeat infections provide incremental protection. With preceding lactogenic immunity, inactivated vaccine provoked increases in existing neutralizing antibody [75]. Further studies on the method of vaccine delivery and boosting illustrated the potential gain that could be present $[75,76]$. Nevertheless, orally administered vaccine proved superior, albeit there are a number of host variables that influence vaccine efficacy [77].

\section{Bovine Coronavirus}

Bovine coronavirus (BCV) causes enteric and respiratory disease, although debilitating enteritis is of considerable consequence in calves. First infections were found to protect against repeat infections [78]. IgA was dominant in feces and mucosal secretions. Second infections augmented IgA (including mucosal) and led to IgG which reacted with most viral proteins except $\mathrm{N}$ and $\mathrm{E} 1$. Colostrum was found to have high antibody levels of E2 and E3 proteins [79]. It was determined that responses to viral proteins varied according to the level of antibody pre-existing in colostrum. Cattle could maintain long-lasting IgA systemically and at the mucosal level including nasal secretions [80]. Egg yolk and colostrum powders prepared from inactivated BCV-vaccinated hens and cows respectively could protect calves when the products were entered into milk [81]. These powders contributed very high titers of neutralization.

A recent review of $\mathrm{BCV}$ and porcine respiratory coronavirus pathogenesis and its application to SARS-CoV-2 was published [82]. Also relevant to human coronavirology, Han et al. provided evidence that bovine coronaviruslike virus could infect humans and potentially create cross-protection [83].

\section{Murine Hepatitis Virus}

Murine hepatitis virus (MHV) can cause respiratory, enteric, and systemic disease. Newborn mice acquire serum IgG and intestinal IgA from previously infected dams [84]. While protective, initiation of feeding must occur in anticipation of challenge and continue thereafter [85]. If maternal mice are infected orally, both $\operatorname{IgG}$ and $\operatorname{IgA}$ are produced. If dams are immunized with killed vaccines, newborns acquire IgG but are not protected [85]. Fab fragments of antibody are protective in themselves, and spike protein can induce a protective immune response [86, 87]. Transgenic mice that expressed a single neutralizing monoclonal antibody to MHV could fully protect suckling mouse litters [88]. These studies generally lack observation for early accentuated disease in immunizationchallenge or challenge-rechallenge studies.

\section{Canine Coronavirus}

Canine coronavirus causes enteric disease in dogs. Animals infected either naturally or under experimental conditions developed fecal IgA [89]. Administration of oral attenuated vaccine led to more $\operatorname{IgA}$ than if the animals were inoculated intramuscularly.

\section{Infectious Bronchitis Virus}

Infectious bronchitis virus of poultry is associated with mainly respiratory illness. There can be viral persistence in animal populations presumably due to serotype variation. Orr-Burks et al. found $\operatorname{IgA}$ mucosal responses after live-attenuated vaccination [90]. Primary infections resulted in IgA responses, but repeat infection was followed by modest incremental IgA but dominant IgG. IgY and IgA can be transferred to offspring through eggs [91].

\section{Duck Enteritis Virus}

Infection of ducks with an attenuated strain is associated with a strong mucosal IgA reactivity and an IgY dominant response in serum [92]. As IgA and IgA-positive plasma cells increase in the intestine, viral load proportionately decreases.

\section{Turkey Coronavirus}

This virus causes enteritis and systemic symptoms. Infection in young poults provokes intestinal IgA [93]. Serum IgA increments correlate with intestinal IgA. 
It must be re-emphasized that many studies lacked observations for challenge-rechallenge or vaccination-challengedirected early accentuated immunological reactivity. Nevertheless, through clinical observation which assesses experimental animals by a variety of physiological parameters, no deterioration is usually described.

\section{Key Applications from Human Coronavirology}

\section{Human Endemic Respiratory Coronaviruses}

Many relevant findings emerged of mucosal and passive immunity for human endemic respiratory coronaviruses. Much of the latter focused on OC43 and 229E which were discovered decades ago [94] In the SARS era, NL63 and HKU1 were discovered [94]. Both 229E and NL63 are Alphacoronaviruses but share as little as $65 \%$ genomic identity. OC43 and HKU1 are Betacoronaviruses but are sufficiently distinct. HKU1 was found to have greater homology with MHV. It is recognized that an antibody-independent inhibition for coronaviruses can exist in sera [95]. There has long been speculation about cross-reactive antibodies between human coronaviruses for conserved domains, but there is potential for humans to be infected with animal coronaviruses which may or may not also share conserved epitopes. For example, workers in poultry processing have higher antibody levels to IBV [96]. Some patients with SARS had increments of antibody to OC43, 229E, and NL63, but those with endemic seropositivity to the latter three coronaviruses did not have SARS-CoV antibody [97]. Potential for cross-reactivity to confuse serological status was discussed for an outbreak [98].

Neutralizing antibody exists in general populations for OC43 and 229E $[99,100]$. Other antibody prevalences correlate variably with neutralizing antibody [101, 102]. It was unclear whether other methods of antibody detection for these viruses could be cross-reactive with MHV [102]. It was also unclear if other measures of antibody (e.g., complement fixation, hemagglutination-inhibition) could confirm exposure, protection, or both [103-105]. In seroepidemiological studies, OC43 antibody was more prevalent than that for 229E [104]. Seroprevalence studies for 229E were method dependent [106]. For those with rises for these other antibodies, simultaneous elevations of neutralizing antibody occurred in $28-67 \%$ [103]. In a student population, levels of neutralizing $229 \mathrm{E}$ antibody did not influence re-infections as judged by complement fixation seroconversions [100]. Increasing neutralizing antibody after re-infection was inversely related to preinfection levels, but about $2 / 3$ who were found to shed virus with active infection had significant rises in neutralizing antibody. Others found protection to correlate with the level of complement-fixing antibody for OC43 [104]. For children who were found to have diagnostic serological responses to 229E, approximately $1 / 3$ had previous antibody [107].
Despite the finding of high endemic seroprevalence for OC43, 229E, NL63, and HKU1, there was a corresponding much lower frequency of related $\operatorname{IgA}$ detection in nasopharyngeal samples [108].

Investigations specific to $229 \mathrm{E}$ have yielded several insights. For a multiyear period, the prevalence of neutralizing antibody varied $11.1-26.7 \%$ [109]. If the degree of seropositivity was low to a homologous strain, the patient was more susceptible to subsequent infection. Subjects were resistant to re-infection with a homologous strain but susceptible to heterologous strains. For volunteer infections, presence of circulating and local neutralizing antibody provided protection [110]. Presence of $\operatorname{IgA}$ shortened viral shedding, but nasal total protein concentrations correlated with protection. For nine volunteers who did not manifest illness or have serological increments after infection, five shed virus. There was a poor correlation of serum and nasal IgA. Low quantitations of serum and nasal $\operatorname{IgA}$ were associated with increased viral shedding, but nasal IgA appeared to be more important. In another volunteer study, low levels of pre-existing antibody correlated with increased susceptibility to challenge [111]. Reinfection 1 year later with a homologous strain was associated with lower viral shedding. Those not evidently infected with initial challenge were successfully infected 1 year later but suffered a more mild illness. The degree of protection to reinfection 1 year later correlated with the amount of nasal IgA. Variation in neutralizing antibodies to $229 \mathrm{E}$ was associated with regional and structural S1 protein changes [112].

\section{Middle East Respiratory Syndrome}

Model studies with MERS-CoV have been difficult since animal hosts were generally uncommon apart from rhesus monkeys. A mouse model was used to assess the parainfluenza vector vaccine [32]. Protective and neutralizing antibody was induced. Vaccine increased survival after challenge. Vector vaccine was superior to inactivated vaccine. Despite the latter protection, both vaccines were associated with increased histopathology after live challenge.

Antibody to MERS-CoV spike protein is commonly found after human infections [113]. For mild infection, neutralizing antibodies less likely occur. Severe infections can be associated with longstanding neutralizing antibody, whereas mild infections may not induce neutralizing antibody or may have short-lived responses [114]. In a small group of patients, longterm neutralizing antibody $\geq 1 / 20$ dilution was present for up to 34 months [115]. For South Korean isolates of MERS$\mathrm{CoV}$, it was found that mutations in the spike protein over time were associated with less neutralization than would be for the initial wild-type [116]. Increased IgA and IgG in nasal secretions were associated with less respiratory virus excretion [117]. Increased neutralizing antibody in serum correlated with lesser respiratory viral RNA [118]. 
One study found an example of a human OC43 infection where cross-reactive antibody to MERS-CoV was determined [113].

\section{Severe Acute Respiratory Syndrome}

Given that SARS-CoV is of similar lineage to SARS-CoV-2, it would seem intuitive that much should be learned from the experience with SARS. Indeed both animal model and human studies have contributed very key information. The method for determining neutralization can evidently have significant impact on the titer, but several assays have been produced $[119,120]$. Despite a correlation, conventional neutralization assays may yield apparent titers in lower dilution than pseudotype virus assays (e.g., S protein-bearing pseudoviruses with murine leukemia virus) [121]. S protein has been the focus for component vaccination. Monoclonal antibodies to $\mathrm{S}$ protein neutralize virus in vitro [122]. Such antibodies can define critical S protein sequences.

In mice, passive serum neutralizing antibody prevented reinfection [123]. In hamsters, neutralizing monoclonal antibodies reduced infectivity [124]. Equine anti-SARS-CoV Fab fragments protected in the hamster model [125]. Human monoclonal antibodies produced in mice neutralized a pseudotype virus; the antibody had anti-S protein properties [126].

A number of serological methods have been used to assess antibody post-vaccine or post-infection, and there is correlation with neutralizing antibody $[127,128]$. Human neutralizing antibody peaks at approximately 5-8 weeks and diminished with a half-life of 6.4 weeks [129]. Such antibody was quantitatively less if the patient's disease had been prolonged. Seronegativity in the context of RT-PCR respiratory specimen-positive patients was seen. Prolonged presence of neutralizing antibody was found with variable kinetics [130]. For convalescent sera of infections, neutralizing antibody could be found up to 7 months postinfection and up to titers ranging from 1:200 to 1:475 [131]. Others found titers of 1:1-1:1000 after 6 months [132]. Longterm neutralizing antibody could be detected in up to $40 \%$ of past SARS patients with titers of 1:10-1:99 by 3 years [133]. Patients surviving SARS tended to have higher neutralizing antibodies in the short term, and these targeted $\mathrm{S}$ and $\mathrm{N}$ proteins [134]. Some non-neutralization assays may be more sensitive for determining anti-SARS-CoV antibody variably for up to 3 years [135-138].

Convalescent patient sera post-infection recognize a limited number of synthetic short viral peptides [139]. Neutralizing antibody may be associated with $\mathrm{S}$ protein antibody, but antigens that did not resolve in gel gradients were also involved in the genesis of neutralization [140]. The latter study stimulated thought on whether all protective antigens are necessarily protein components. Neutralizing antibody to $\mathrm{S}$ protein can recognize both native and denatured versions [141]. The human anti-SARS-CoV immune response has been mapped with recombinant proteins, and there was generally good reactivity to proteins $\mathrm{S}, 3 \mathrm{a}, \mathrm{N}$, and $9 \mathrm{~b}$ but not to proteins $\mathrm{E}, \mathrm{M}, 3 \mathrm{~b}, 6$, and 7
[142]. Of S, 3a, N, and 9b, only antibody to S gave neutralizing antibody efficacy. Antibody to $\mathrm{S}$ protein receptor-binding domain (RBD) was neutralizing [137]. Others found good human $\mathrm{IgG}$ responses to $\mathrm{S}$ and $\mathrm{N}$ proteins, but again neutralization better correlated with the response to S protein [143].

Rabbit antisera to proteins $\mathrm{S}$ and $\mathrm{M}$ rendered neutralization but not antisera to protein $\mathrm{N}$ [144]. A recombinant parainfluenza virus vector vaccine induced a high titer of neutralizing antibody if the $S$ protein was included but not when $\mathrm{M}, \mathrm{E}$, or $\mathrm{N}$ proteins were introduced alone [145]. The recombinant bearing $\mathrm{S}$ protein was also said to be protective in the mouse model, but early accentuated inflammation was not examined. Recombinant $\mathrm{S}$ proteinexpressing Lactobacillus casei could induce serum and mucosal antibodies [146]. The oral route of administration was superior to nasal. S protein sequences of relevance promoted the formation of neutralizing antibody. It must be acceded however that neutralization escape mutants can be elicited under experimental conditions [147]. Ankara vaccinia vector-expressing S protein gave partial protection [148]. This vector promoted the development of neutralizing antibody [149]. Unfortunately, this vaccine also led to the hyperaccentuated response after challenge in a ferret model which some have labelled as antibody-dependent enhancement (ADE) $[150,151]$. The latter research had followed what had been preliminarily determined as protection in a live challenge-rechallenge model [152]. Using another virus-based vector bearing S protein, Deming et al. found that protection failed and enhanced histopathology was induced [153]. The combined use of two vector vaccines in sequence boosted neutralizing antibodies compared to the single use of each vector [154].

Formalin-inactivated vaccine with adjuvant given intranasally to mice induced high titers of neutralizing antibody [155]. Such antibody was also found in the tracheal/lung lavage. IgA was also found in lung wash but again only if the vaccine was administered with adjuvant. Both adjuvant and route of immunization have considerable impact on neutralizing antibody generation [156]. In another murine experiment, killed virus vaccine produced better titers of neutralizing antibodies compared to an adenovirus-vectored vaccine, but the latter provoked the development of serum IgA [157]. Formalin-inactivated vaccine induced serum and mucosal antibodies in monkeys [158]. IgA could be detected in nasal washes, and there was a doseresponse for the overall vaccine effect.

Given the propensity for early accentuated responses in animal models, a live-attenuated vaccine was produced that was defective in the E gene [159]. The latter raised protective antibody and was seemingly spared of early recall immune phenomena. Others have attempted to engineer peptidebased vaccines for the $\mathrm{S}$ protein that spare the potential for presumed ADE [160]. S protein vaccines in hamsters induced fecal IgG and IgA antibodies [161]. Repeat vaccination and adjuvant promoted the humoral response. The antibodies generated were neutralizing, and there was no apparent postchallenge enhancement. 


\section{COVID-19}

Trials of specific human vaccines are not detailed herein, but there are studies of COVID-19 immunity that otherwise merit discussion. Most have focused on post-infection humoral immunity as a diagnostic marker especially with commercial kits. Of over 700 sera from uninfected patients, no neutralizing antibodies were found [162]. Severe disease was associated with earlier anti-SARS-CoV-2 antibody, and peak neutralizing antibody arose by approximately $2 \frac{1}{2}$ weeks. Stereotypic antibody responses to SARS-CoV-2 led some to believe that there should be cross-reactivity with SARS-CoV in the constant RBD [163]. In both humans and animals, such crossreactivity was suspected to be due to non-neutralizing anti-S antibody again likely relating to a conserved region [164]. Cross-neutralization was however uncommon. Advances in technology will allow for the creation of templates for various virus proteins that can be used to determine specific immunoreactivity [165].

Several animal models of COVID-19 have emerged [166]. In the rhesus monkey, neutralizing antibody correlates with protection in re-infection [167]. Human monoclonal antibodies that recognize the RBD and S trimer conformations gave passive protection in mice and monkeys [168]. Monoclonal antibodies from convalescing patients can have both preventative and therapeutic effects [169]. Such data appear to have been the harbinger for the recent findings of Abolghasemi et al. in which convalescent patient sera provided some partial disease mitigation [170]. Liu and others have developed neutralizing monoclonal antibodies [171].

In humans, S-specific antibody is dominant and correlates with neutralization [172]. The latter study assessed $\mathrm{T}$ helper immunity in convalescent sera and found that the $\mathrm{T}$ helper phenotype can potentially differentiate patients with strong neutralizing responses. There was lower specificity for RBD. Others found a correlation between neutralizing antibody and virus-directed $T$ cells [173]. Human monoclonal antibodies that neutralize virus or pseudovirus especially recognized the RBD [174]. Reactive T cells in patients with COVID-19, SARS, and controls were found to have some cross-reactive potential with human endemic respiratory coronaviruses and animal coronaviruses of the Betacoronavirus lineage [175]. SARS-CoV-2 memory cells were found in convalescent patients. Weisberg et al. have found diversity in immune responses contingent on the nature of presenting disease [176].

A vesicular stomatitis virus-S vector has induced neutralizing antibodies in mice [177]. Passive transfer of these antibodies protects mice, and vaccination decreases both pathology of lung disease and viral load. It was suggested the RBD site was being targeted.

Arvin and colleagues remind us of the potential for ADE, but caution as to whether that seen in other model systems necessarily has the same pathogenesis as for any that may be seen for SARS-CoV-2 or for what had been experienced with SARS-CoV [178]. It should also be cautioned that the mechanism of this phenomenon may not necessarily be that which is commonly postulated for ADE. Furthermore, as the intensity of COVID-19 may evolve into what some have said is an immunological storm, the ADE phenomenon has been entered into discussions about the immediate pathogenesis, even after first infection. There is jeopardy in simply assuming that such events parallel the post-vaccination ADE or similar events.

\section{An Integration of Immune Instincts and Maternal Intelligence for COVID-19}

As studies in SARS-CoV-2 immunity and vaccinology emerge, it is never too late to learn from the past, and the common mucosal immune system has much to say. That system is the gateway to instinctual adaptive responses which include by example the maternal immunity that is sufficiently intelligent to discern how protection should be distinguished from harm. Data from SARS, MERS, or now COVID-19 have and will continue to corroborate the latter.

From a purist's perspective, neutralizing antibody postinfection or post-vaccination presents the best humoral immune correlate with protection at this time [179]. Mucosal $\operatorname{sIgA}$ and systemic $\operatorname{IgG}$ at this time also best correlate with local and peripheral protection respectively. Some patient exposures to infection or vaccination do not generate protective antibodies. Some exposures may be followed by low-grade protection or anamnestic responses much later. High levels of protective antibody measures can follow infection or vaccination and may last for years. Although the latter have a good correlation with protection, this is not an all-or-none effect. Even in the best case scenario, high neutralizing antibodies diminish over months to years. There is general belief that protection best correlates with antibody that is directed to domains on the $\mathrm{S}$ protein and a few others alone or together. Even if fundamentally true, the latter does not exclude protection that may arise from antibody or other immune responses to non-protein antigens or protein-containing antigens that do not withstand laboratory-based denaturation events in immunolabelling studies. Simultaneous study of related cell-mediated immune responses is imperative both theoretically and practically.

Repeat immunizations, titration of tolerable dosing, routes of administration, and adjuvancy will all have their influential roles in particular contexts. Inactivated whole-cell vaccines will be achieved, but the best approaches to administration and the duration of protection are indeterminate at this time. The method of virus inactivation that thereafter greatly influences antigen presentation will be one of the major hurdles towards fine-tuning efficacy and safety. Other forms of vaccination are potentially many, and there are sufficient nuances 
among them that present complex logistic issues for immune generation and safety. In general, the approaches to vaccination may vary the nature of response systemically, at the mucosal level, or both. Where do we want the protection to begin? Vaccine variability will determine whether the products will facilitate primary prevention or foster protection in the pathways of immunopathogenesis post-infection, or both. For protection, route of immunization can affect subsets of the common mucosal immune system differentially. Each of the respiratory mucosa, gastrointestinal mucosa, or lactogenic factory may be productive of protective antibody but quantitatively variable. Each of the latter can also share that immunity with other mucosal sites. For a predominantly respiratory infection, nasal and oropharyngeal SIgA is a prime candidate for being the first level of defense. Oral vaccination carries potential jeopardy even when seemingly protective-is the effect due to protection or is the common mucosal immune system simply developing an antigenic immunotolerance?

What level of protection is acceptable? The major influenza vaccines are routinely recommended and accepted, and yet year-to-year protection is quite variable and at times approaching only $35-75 \%$ protection for a given strain in a given year. For COVID-19, the ongoing pandemic and the future severity of illness will determine how vaccine uptake should be promoted and whether it will be an ongoing requisite. Time will also tell whether the phenomenon of escape mutation or genetic drift will alter the patterns of SARS-CoV-2 presence and immune recognition.

Phenomena of early accentuated and potentially harmful immunopathology after re-infection or vaccination are real. Whether called ADE generically, or whether ADE is only a subset, it must be assessed both in laboratory and vaccine trials. What is promising in this regard, however, is that there are clear solutions should it be observed. Taking $M$. pneumoniae research as a strong example, early findings of vaccine adversity in humans and animal models had been fully or partially overcome. Although not adopted, the very large trials of inactivated $M$. pneumoniae vaccine were not associated with such an adverse event. What is also reassuring is that passive immunity, whether parenteral or lactogenic, was not largely associated with such pathology in model systems. Conceptually, the latter should open up the theme of passive immune treatment considerably. That SARS-CoV-2 is an intracellular pathogen provides one measure of cloaking from the start. Mobilization of virus from cell to cell in functional syncytia may prove to be the second viral cloaking device. The latter then brings us full circle to the importance of attempting to target primary prevention.

In vitro experiments, animal models, and early phases of vaccine trials in humans offer correlates that are critical to assimilate, and may predict what to expect or avoid, but ultimately large-scale human trials are required. The latter are critical to the refinement of any potential preventative strategy. The immune system, and certainly the common mucosal immune system, has in large part mechanisms that facilitate our understanding. Mucosal immunity, mostly through sIgA, is capable of telling us what the body needs to create for protection. As it has already provided these secrets by way of protective lactogenic immunity, it is quite likely that such immune informatics can be exploited easily and expeditiously. As systemic IgA is a concomitant of infection or vaccination and may create some confusion if and when it enters the mucosal sites inadvertently, probing for sIgA should be conducted with labels that recognize the $\mathrm{S}$ chain of $\operatorname{IgA}$ dimers. sIgA could then be used as a probe for what the lactogenic immunity, and therefore the common mucosal immune system generally, sees as being protective and yet not deleterious, e.g., distinguishable protective epitopes. Lactogenic immunity is unlikely to select for epitopes that facilitate early hyperimmune reactivity or ADE. With the latter likelihood, there is another selfish attribute to such discovery-milk sources whether human, bovine, caprine, or ovine (or IgY from eggs) could be made to carry protective immunity as a preventative passive strategy for humans. However theoretical or futuristic at this time, such a preventative approach could obviate the need for repeat immunizations should SARS-CoV-2 become endemic. Transplacental antibody in newborn blood might initially be considered another avenue for determining protection, but such antibody does not equate to SIgA, and transplacentally acquired $\operatorname{IgG}$ is non-selectively mobilized as in other viral infections.

\section{Conclusion}

Effective and relatively safe vaccine(s) for COVID-19 will emerge. There is simply too much scientific ingenuity for this not to happen. What is not clear is whether vaccines will be highly protective, how long immunity will last, and whether ADE or similar post-infection or post-vaccination events will be experienced. There is no guarantee that in vitro and animal model studies will sufficiently predict the latter. Critical key knowledge aspects will come directly from human vaccine experiments much like the large vaccine trials of the 1950s1970s albeit with contemporary approaches. In the interim, studies in these regards will produce valuable spin-offs that are applicable to passive immunity, vaccine safety, disease pathogenesis, treatment, and diagnostics. There are no grounds for absolute pessimism because proactive and cautious initiatives will eventually succeed more or less. The latter must necessarily occur given the majority of success in other viral vaccines. The common mucosal immune system, and the subset of lactogenic immunity, can provide critical informatics.

Data Availability Not applicable. 


\section{Compliance with Ethical Standards}

Conflict of Interest The author declares that he has no conflict of interest.

Ethics Approval Not applicable.

Consent to Participate Not applicable.

Consent for Publication Not applicable.

Code Availability Not applicable.

\section{References}

1. Ahn D-G, Shin H-J, Kim M-H, Lee S, Kim H-S, Myoung J, et al. Current status of epidemiology, diagnosis, therapeutics, and vaccines for novel coronavirus disease 2019 (COVID-19). J Microbiol Biotechnol. 2020;30(3):313-24.

2. Amanat F, Krammer F. SARS-CoV-2 vaccines: status report. Immunity. 2020;52(4):583-9.

3. Moore JP, Klasse PJ. SARS-CoV-2 vaccines: 'Warp Speed' needs mind melds not warped minds. J Virol. 2020; JVI.01083-20. https://doi.org/10.1128/JVI.01083-20.

4. Poland GA. Tortoises, hares, and vaccines: a cautionary note for SARS-CoV-2 vaccine development. Vaccine. 2020;38(27):421920.

5. Eaton MD, Meiklejohn G, van Herick W. Studies on the etiology of primary atypical pneumonia: a filterable agent transmissible to cotton rats, hamsters, and chick embryos. J Exp Med. 1944;79(6): 649-68.

6. Roberts A, Vogel L, Guarner J, Hayes N, Murphy B, Zaki S, et al. Severe acute respiratory syndrome coronavirus infection of Golden Syrian hamsters. J Virol. 2005;79(1):503-11.

7. Chan JF, Zhang AJ, Yuan S, Poon VK, Chan CC, Lee AC, et al. Simulation of the clinical and pathological manifestations of coronavirus disease 2019 (COVID-19) in Golden Syrian hamster model: implications for disease pathogenesis and transmissibility. Clin Infect Dis. 2020. https://doi.org/10.1093/cid/ciaa325.

8. Hayatsu E, Kawakubo Y, Yayoshi M, Araake M, Wakai M, Yoshida A, et al. Immunological responses of hamsters in the acquired immune state to Mycoplasma pneumoniae infection. Microbiol Immunol. 1981;25(12):1255-63.

9. Cimolai N, Cheong A, Taylor G, Morrison B. Passive immunization with polyclonal antisera does not result in early accentuated histopathological responses after live challenge in an animal model of Mycoplasma pneumoniae infection. Chest. 1996;110(4): S167.

10. Cimolai N, Cheong AC, Morrison BJ, Taylor GP. Mycoplasma pneumoniae reinfection and vaccination: protective oral vaccination and harmful immunoreactivity after re-infection and parenteral immunization. Vaccine. 1996;14(15):1479-83.

11. Cimolai N, Taylor GP, Mah D, Morrison BJ. Definition and application of a histopathological scoring scheme for an animal model of acute Mycoplasma pneumoniae pulmonary infection. Microbiol Immunol. 1992;36(5):465-78.

12. Cimolai N, Mah DG, Taylor GP, Morrison BJ. Bases for the early immune response after rechallenge or component vaccination in an animal model of acute Mycoplasma pneumoniae pneumonitis. Vaccine. 1995;13(3):305-9.

13. Szczepanek SM, Majumder S, Sheppard ES, Liao X, Rood D, Tulman ER, et al. Vaccination of BALB/c mice with an avirulent
Mycoplasma pneumoniae P30 mutant results in disease exacerbation upon challenge with a virulent strain. Infect Immun. 2012;80(3):1007-14.

14. Fernald GW, Clyde WA Jr, Bienenstock J. Immunoglobulincontaining cells in lungs of hamsters infected with Mycoplasma pneumoniae. J Immunol. 1972;108(5):1400-8.

15. Fernald GW, Clyde WA Jr. Protective effect of vaccines in experimental Mycoplasma pneumoniae disease. Infect Immun. 1970;1(6):559-65.

16. Cimolai N, Cheong A. Oral vaccination adjuvants in an animal model of Mycoplasma pneumoniae infection. Chest. 1996;110(4): $167 \mathrm{~S}$.

17. Cimolai N, Cheong ACH, Taylor GP, Morrison B. Oral immunization with Mycoplasma pneumoniae is associated with decreased pulmonary histopathology after challenge in an animal model. Immunol Cell Biol. 1997;75(Suppl 1):A29.

18. Barile MF, Grabowski MW, Kapatais-Zoumbois K, Brown B, Hu PC, Chandler DK. Protection of immunized and previously infected chimpanzees challenged with Mycoplasma pneumoniae. Vaccine. 1994;12(8):707-14.

19. Luo F, Liao FL, Wang H, Tang HB, Yang ZQ, Hou W. Evaluation of antibody-dependent enhancement of SARS-CoV infection in Rhesus macaques immunized with an inactivated SARS-CoV vaccine. Virol Sin. 2018;33(2):201-4.

20. Zaher A, Cimolai N. Comparison of three scoring methods for the pulmonary pathology in an animal model of Mycoplasma pneumoniae infection. Clin Invest Med. 1997;20(Suppl):S55.

21. Yasui F, Kai C, Kitabatake M, Inoue S, Yoneda M, Yokochi S, et al. Prior immunization with severe acute respiratory syndrome (SARS)-associated coronavirus (SARS-CoV) nucleocapsid protein causes severe pneumonia in mice infected with SARS-CoV. J Immunol. 2008;181(9):6337-48.

22. Meyer Sauteur PM, de Bruijn ACJM, Graça C, Tio-Gillen AP, Estevão SC, Hoogenboezem T, et al. Antibodies to protein but not glycolipid structures are important for host defense against Mycoplasma pneumoniae. Infect Immun. 2019;87(2):e00663-18.

23. Brunner H. Protective efficacy of Mycoplasma pneumoniae polysaccharides. Isr J Med Sci. 1981;17(7):678-81.

24. Olsen CW. A review of feline infectious peritonitis virus: molecular biology, immunopathogenesis, clinical aspects, and vaccination. Vet Microbiol. 1993;36(1-2):1-37.

25. Bolles M, Deming D, Long K, Agnihothram S, Whitmore A, Ferris $\mathrm{M}$, et al. A double-inactivated severe acute respiratory syndrome coronavirus vaccine provides incomplete protection in mice and induces increased eosinophilic proinflammatory pulmonary response upon challenge. J Virol. 2011;85(23):12201-15.

26. Yip MS, Leung HL, Li PH, Cheung CY, Dutry I, Li D, et al. Antibody-dependent enhancement of SARS coronavirus infection and its role in the pathogenesis of SARS. Hong Kong Med J. 2016;22(3 Suppl 4):25-31.

27. Wan Y, Shang J, Sun S, Tai W, Chen J, Geng Q, et al. Molecular mechanism for antibody-dependent enhancement of coronavirus entry. J Virol. 2020;94(5):e02015-9.

28. Grayston JT, Woolridge RL, Wang S-p. Trachoma vaccine studies on Taiwan. Ann N Y Acad Sci. 1962;98:352-67.

29. Weiss RC, Scott FW. Antibody-mediated enhancement of disease in feline infectious peritonitis: comparisons with dengue hemorrhagic fever. Comp Immunol Microbiol Infect Dis. 1981;4(2): 175-89.

30. Prince GA, Bennett Jenson A, Hemming VG, Murphy BR, Walsh EE, Horswood RL, et al. Enhancement of respiratory syncytial virus pulmonary pathology in Cotton rats by prior intramuscular inoculation of formalin-inactivated virus. J Virol. 1986;57(3): $721-8$.

31. Delgado MF, Coviello S, Monsalvo AC, Melendi GA, Hernandez JZ, Batalle JP, et al. Lack of antibody affinity maturation due to 
poor Toll-like receptor stimulation leads to enhanced respiratory syncytial virus disease. Nat Med. 2009;15(1):34-41.

32. Li K, Li Z, Wohlford-Lenane C, Meyerholz DK, Channappanavar $\mathrm{R}$, An D, et al. Single-dose, intranasal immunization with recombinant parainfluenza virus 5 expressing Middle East respiratory syndrome coronavirus (MERS-CoV) spike protein protects mice from fatal MERS-CoV infection. mBio. 2020;11(2):e00554-20.

33. Couch RB, Cate TR, Chanock RM. Infection with artificially propagated Eaton agent (Mycoplasma pneumoniae): implications for development of attenuated vaccine for cold agglutinin-positive pneumonia. JAMA. 1964;187:442-7.

34. Senterfit LB, Jensen KE. Progress in the immunoprophylaxis of M. pneumoniae infection. Ann N Y Acad Sci. 1967;143(1):46170.

35. Smith CB, Friedewald WT, Chanock RM. Inactivated Mycoplasma pneumoniae vaccine: evaluation in volunteers. JAMA. 1967;199(6):353-8.

36. Weibel RW, Stokes J Jr, Mascoli CC, Leagus MB, Woodhour AF, Tytell AA, et al. Respiratory virus vaccines. VII. Field evaluation of respiratory syncytial, parainfluenza 1,2,3, and Mycoplasma pneumoniae vaccines, 1965-1966. Am Rev Respir Dis. 1967;96(4):724-39.

37. Steinberg P, White RJ, Fuld SL, Gutekunst RR, Chanock RM, Senterfit LB. Ecology of Mycoplasma pneumoniae infections in Marine recruits at Parris Island, South Carolina. Am J Epidemiol. 1969;89(1):62-73.

38. Brown RC, Hendley JO, Gwaltney JM Jr. Mycoplasma pneumoniae vaccine: antigenicity of buffered antigens in volunteers. Infect Immun. 1972;5(5):657-61.

39. Fernald GW, Glezen WP. Humoral and cellular immune responses to an inactivated Mycoplasma pneumoniae vaccine in children. J Infect Dis. 1973;127(5):498-504.

40. Brunner H, Greenberg HB, James WD, Horswood RL, Couch RB, Chanock RM. Antibody to Mycoplasma pneumoniae in nasal secretions and sputa of experimentally infected human volunteers. Infect Immun. 1973;8(4):612-20.

41. Mogabgab WJ. Protective efficacy of killed Mycoplasma pneumoniae vaccine measured in large-scale studies in a military population. Am Rev Respir Dis. 1973;108(4):899-908.

42. McCormick DP, Wenzel RP, Senterfit LB, Beam WE Jr. Relationship of pre-existing antibody to subsequent infection by Mycoplasma pneumoniae in adults. Infect Immun. 1974;9(1):539.

43. Wenzel RP, Craven RB, Davies JA, Hendley JO, Hamory BH, Gwaltney JM Jr. Field trial of an inactivated Mycoplasma pneumoniae vaccine. I. Vaccine efficacy. J Infect Dis. 1976;134(6):571-6.

44. Sweet BH, Tytell AA, Potash L, Weibel RE, Stokes J Jr, Drake $\mathrm{ME}$, et al. Respiratory virus vaccines. III. Pentavalent respiratory syncytial-parainfluenza-Mycoplasma pneumoniae vaccine. Am Rev Respir Dis. 1966;94(3):340-9.

45. Cimolai N. Chapter 7. Inhibitory antibody. In: Cimolai N, editor. Serodiagnosis of the infectious diseases: Mycoplasma pneumoniae. Boston: Kluwer Academic Publishers; 1999.

46. Smith CB, Chanock RM, Friedewald WT, Alford RH. Mycoplasma pneumoniae infections in volunteers. Ann N Y Acad Sci. 1967;143(1):471-83.

47. Katsura T, Kanamori M, Kitamoto O, Ogata S. Protective effect of colostrum in Mycoplasma pneumoniae infection induced in infant mice. Microbiol Immunol. 1985;29(9):883-94.

48. Macadam S, Cimolai N. Anti-Mycoplasma pneumoniae secretory antibody in human breast milk. Diagn Microbiol Infect Dis. 2002;43(3):247-50.

49. Cimolai N. Defining protective epitopes for COVID-19 vaccination models. J Med Virol. 2020. https://doi.org/10.1002/jmv. 25876 .
50. Abou-Youssef MH, Ristic M. Protective effect of immunoglobulins in serum and milk of sows exposed to transmissible gastroenteritis virus. Can J Comp Med. 1975;39(1):41-5.

51. Sprino PJ, Morilla A, Ristic M. Intestinal immune response of feeder pigs to infection with transmissible gastroenteritis virus. Am J Vet Res. 1976;37(2):171-5.

52. De Diego M, Laviada MD, Enjuanes L, Escribano JM. Epitope specificity of protective lactogenic immunity against swine transmissible gastroenteritis virus. J Virol. 1992;66(11):6502-6.

53. Morilla A, Klemm RC, Sprino P, Ristic M. Neutralization of a transmissible gastroenteritis virus of swine by colostral antibodies elicited by intestine and cell culture-propagated virus. Am J Vet Sci. 1976;37(9):1011-6.

54. Stone SS, Kemeny LJ, Woods RD, Jensen MT. Efficacy of isolated colostral $\operatorname{IgA}, \operatorname{IgG}$, and $\operatorname{IgM}(\mathrm{A})$ to protect neonatal pigs against the coronavirus of transmissible gastroenteritis. Am J Vet Sci. 1977;38(9):1285-8.

55. Mocsari E, Stone SS. Colostral IgA, IgG, and IgM-IgA fractions as fluorescent antibody for the detection of the coronavirus of transmissible gastroenteritis. Am J Vet Res. 1978;39(9):1442-6.

56. Kaji T, Shimizu Y. Passive immunization against transmissible gastroenteritis virus in piglets by ingestion of milk of sows inoculated with attenuated virus. Natl Inst Anim Health Q (Tokyo). 1978;18(2):43-52.

57. Lanza I, Shoup DI, Saif LJ. Lactogenic immunity and milk antibody isotypes to transmission gastroenteritis virus in sows exposed to porcine respiratory coronavirus during pregnancy. Am J Vet Res. 1995;56(6):739-48.

58. Nguyen TD, Bottreau E, Bernard S, Lantier I, Aynaud JM. Neutralizing secretory IgA and IgG do not inhibit attachment of transmissible gastroenteritis. J Gen Virol. 1986;67(Pt 5):939-43.

59. Thorsen J, Djurickovic S. Experimental immunization of sows with inactivated transmissible gastroenteritis (TGE) virus. Can J Comp Med. 1971;35(2):99-102.

60. Bernard S, Shirai J, Lantier I, Bottreau E, Aynaud JM. Lactogenic immunity to transmissible gastroenteritis (TGE) of swine induce by the attenuated Nouzilly strain of TGE virus: passive protection of piglets and detection of serum and milk antibody classes by ELISA. Vet Immunol Immunopathol. 1990;24(1):37-47.

61. Moxley RA, Olson LD, Solorzano RF. Relationship among transmissible gastroenteritis virus antibody titers in serum, colostrum, and milk from vaccinated sows, and protection in their suckling pigs. Am J Vet Res. 1989;50(1):119-25.

62. Smerdou C, Anton IM, Plana J. Curtiss $3^{\text {rd }}$ R, Enjuanes L. A continuous epitope from transmissible gastroenteritis virus $\mathrm{S}$ protein fused to E. coli heat-labile toxin B subunit expressed by attenuated Salmonella induces serum and secretory immunity. Virus Res. 1996;41(1):1-9.

63. Castilla J, Sola I, Enjuanes L. Interference of coronavirus infection by expression of immunoglobulin $\mathrm{G}$ ( $\operatorname{IgG}$ ) or IgA virusneutralizing antibodies. J Virol. 1997;71(7):5251-8.

64. Tang L, Li Y. Oral immunization of mice with recombinant Lactococcus lactis expressing porcine transmissible gastroenteritis virus spike glycoprotein. Virus Genes. 2009;39:238-45.

65. Terao Y, Takagi H, Phan TG, Okitsu S, Ushijima H. Identification of antibody against porcine coronavirus in human milk. Clin Lab. 2007;53(3-4):129-30.

66. Castilla J, Pintado B, Sola L, Sánchez-Morgado JM, Enjuanes L. Engineering passive immunity in transgenic mice secreting virusneutralizing antibodies in milk. Nat Biotechnol. 1998;16(4):34954.

67. Callebaut P, Cox E, Pensaert M, Van Deun K. Induction of milk IgA antibodies by porcine respiratory coronavirus infection. Adv Exp Med Biol. 1990;276:421-8.

68. De Diego M, Rodriguez F, Alcaraz C, Gómez N, Alonso C, Escribano JM. Characterization of the IgA and subclass IgG 
responses to neutralizing epitopes after infection of pregnant sows with the transmissible gastroenteritis virus or the antigenically related porcine respiratory coronavirus. J Gen Virol. 1994;75(Pt 10):2585-93.

69. Sestak K, Lanza I, Park SK, Weilnau PA, Saif LJ. Contribution of passive immunity to porcine respiratory coronavirus to protection against transmissible gastroenteritis virus challenge exposure in suckling pigs. Am J Vet Res. 1996;57(5):664-71.

70. Saif LJ. Mucosal immunity: an overview and studies of enteric and respiratory coronavirus infections in a swine model of enteric disease. Vet Immunol Immunopathol. 1996;54(1-4):163-9.

71. Langel SN, Chimelo Paim F, Lager KM, Vlasova AN, Saif LJ. Lactogenic immunity and vaccines for porcine epidemic diarrhea virus (PEDV): historical and current concepts. Virus Res. 2016;226:93-107.

72. de Arriba ML, Carvajal A, Pozo J, Rubio P. Mucosal and systemic istotype-specific antibody responses and protection in conventional pigs exposed to virulent or attenuated porcine epidemic diarrhoea virus. Vet Immunol Immunopathol. 2002;85(1-2):85-97.

73. Song Q, Stone S, Drebes D, Greiner LL, Dvorak CMT, Murtaugh MP. Characterization of anti-porcine epidemic diarrhea virus neutralizing activity in mammary secretions. Virus Res. 2016;226: 85-92.

74. Poonsuk K, Zhang J, Chen Q, Gonzalez W. Correa da Silva Carrion L, Sun Y, et al. Quantifying the effect of lactogenic antibody on porcine epidemic diarrhea virus infection in neonatal piglets. Vet Microbiol. 2016;197:83-92.

75. Gillespie T, Song Q, Inskeep M, Stone S, Murtaugh MP. Effect of booster vaccination with inactivated porcine epidemic diarrhea virus on neutralizing antibody response in mammary secretions. Viral Immunol. 2018;31(1):62-8.

76. Wen Z, Xu Z, Zhou Q, Li W, Wu Y, Du Y, et al. A heterologous 'prime-boost' anti-PEDV immunization for pregnant sows protects neonatal piglets through lactogenic immunity against PEDV. Lett Appl Microbiol. 2019;69(4):258-63.

77. Langel SN, Wang Q, Vlasova AN, Saif LJ. Host factors affecting generation of immunity against porcine epidemic diarrhea virus in pregnant and lactating swine and passive protection of neonates. Pathogens. 2020;9(2):130.

78. Heckert RA, Saif LJ, Mengel JP, Myers GW. Isotype-specific antibody responses to bovine coronavirus structural proteins in serum, feces, and mucosal secretions from experimentally challenge-exposed colostrum-deprived calves. Am J Vet Res. 1991;52(5):692-9.

79. Heckert RA, Saif LJ, Mengel JP, Myers GW. Mucosal and systemic antibody responses to bovine coronavirus structural proteins in experimentally challenge-exposed calves fed low or high amounts of colostral antibodies. Am J Vet Res. 1991;52(5):700-8.

80. Tråvén M, Näslund K, Linde N, Silván A, Fossum C, Hedlund $\mathrm{KO}$, et al. Experimental reproduction of winter dysentery in lactating cows using $\mathrm{BCV}$ - comparison with $\mathrm{BCV}$ infection in milkfed calves. Vet Microbiol. 2001;81(2):127-51.

81. Ikemori Y, Ohta M, Umeda K, Icatio FC Jr, Kuroki M, Yokoyama $\mathrm{H}$, et al. Passive protection of neonatal calves against bovine coronavirus-induced diarrhea by administration of egg yolk or colostrum antibody powder. Vet Microbiol. 1997;58(2-4):105-11.

82. Saif LJ, Jung K. Comparative pathogenesis of bovine and porcine respiratory coronaviruses in the animal host species and SARSCoVo-2 in humans. J Clin Microbiol. 2020;JCM.01355-20. https://doi.org/10.1128/JCM.01355-20.

83. Han MG, Cheon D-S, Zhang X, Saif LJ. Cross-protection against a human enteric coronavirus and a virulent bovine enteric coronavirus in gnotobiotic calves. J Virol. 2006;80(24):12350-6.

84. Homberger FR. Maternally-derived passive immunity to enterotropic mouse hepatitis virus. Arch Virol. 1992;122(1-2): $133-41$.
85. Homberger FR, Barthold SW. Passively acquired challenge immunity to enterotropic coronavirus in mice. Arch Virol. 1992;126(1-4):35-43.

86. Daniel C, Talbot PJ. Protection from lethal coronavirus infection by affinity-purified spike glycoprotein of murine hepatitis virus, strain A59. Virology. 1990;174(1):87-94.

87. Lamarre A, Talbot PJ. Protection from lethal coronavirus infection by immunoglobulin fragments. J Immunol. 1995;154(8):3975-84.

88. Kolb AF, Pewe L, Webster J, Perlman S, Whitelaw CB, Siddell SG. Virus-neutralizing monoclonal antibody expressed in milk of transgenic mice provides full protection against virus-induced encephalitis. J Virol. 2001;75(6):2803-9.

89. Decaro N, Pratelli A, Tinelli A, Martella V, Camero M, Buonavoglia D, et al. Fecal immunoglobulin A antibodies in dogs infected or vaccinated with canine coronavirus. Clin Diagn Lab Immunol. 2004;11(1):102-5.

90. Orr-Burks N, Gulley SL, Toro H, van Ginkel FW. Immunoglobulin A as an early humoral responder after mucosal avian coronavirus vaccination. Avian Dis. 2014;58(2):279-86.

91. Hamal KR, Burgess SC, Pevzner IY, Erf GF. Maternal antibody transfer from dams to their egg yolks, egg whites, and chicks in meat lines of chickens. Poult Sci. 2006;85(8):1364-72.

92. Yang X, Qi X, Cheng A, Wang M, Zhu D, Jia R, et al. Intestinal mucosal immune response in ducklings following oral immunization with an attenuated duck enteritis virus vaccine. Vet J. 2010;185(2):199-203.

93. Loa CC, Lin TL, Wu CC, Bryan T, Hooper T, Schrader D, et al. Specific mucosal IgA immunity in turkey poults infected with turkey coronavirus. Vet Immunol Immunopathol. 2002;88(1-2): 57-64.

94. Cimolai N. Complicating infections associated with common endemic human respiratory coronaviruses. Health Security. 2020;9(2) in press.

95. Debiaggi M, Luini M, Cereda PM, Perduca M, Romero E. Serum inhibitor of coronaviruses OC43 and NCDCV: a study in vivo. Microbiologica. 1986;9(1):33-7.

96. Pedersden KA, Sadasiv EC, Chang PW, Yates VJ. Detection of antibody to avian viruses in human populations. Epidemiol Infect. 1990;104(3):519-25.

97. Chan KH, Cheng VCC, Woo PCY, Lau SKP, Poon LLM, Guan $\mathrm{Y}$, et al. Serological responses in patients with severe acute respiratory syndrome coronavirus infection and cross-reactivity with human coronaviruses 229E, OC43, and NL63. Clin Diagn Lab Immunol. 2005;12(11):1317-21.

98. Patrick DM, Petric M, Skowronski DM, Guasparini R, Booth TF, Krajden M, et al. An outbreak of human coronavirus OC43 infection and serological cross-reactivity with SARS coronavirus. Can J Infect Dis Med Microbiol. 2006;17(6):330-6.

99. McIntosh K, Kapikian AZ, Hardison KA, et al. Antigenic relationships among the coronaviruses of man and between human and animal coronaviruses. J Immunol. 1969;102(5):1109-18.

100. Hamre D, Beem M. Virologic studies of acute respiratory disease in young adults. V. Coronavirus 229E infections during six years of surveillance. Am J Epidemiol. 1972;96(2):94-106.

101. McIntosh K, Kapikian AZ, Turner HC, Hartley JW, Parrott RH, Chanock RM. Seroepidemiologic studies of coronavirus infection in adults and children. Am J Epidemiol. 1970;91(6):585-92.

102. McIntosh K, Chao RK, Krause HE, Wasil R, Mocega HE, Mufson MA. Coronavirus infection in acute lower respiratory tract disease of infants. J Infect Dis. 1974;130(5):502-7.

103. Monto AS, Lim SK. The Tecumseh study of respiratory illness. VI. Frequency of and relationship between outbreaks of coronavirus infection. J Infect Dis. 1974;129(3):271-6.

104. Wenzel RP, Hendley JO, Davies JA, Gwaltney JM Jr. Coronavirus infections in military recruits: three-year study with 
coronavirus strains OC43 and 229E. Am Rev Respir Dis. 1974;109(6):621-4.

105. Ukkonen P, Hovi T, von Bonsdorff CH, Saikku P, Pentinnen K. Age-specific prevalence of complement-fixing antibodies to sixteen viral antigens: a computer analysis of 58,500 patients covering a period of eight years. J Med Virol. 1984;13(2):131-48.

106. Gerna G, Achilli G, Cattaneo E, Cereda P. Determination of coronavirus $229 \mathrm{E}$ antibody by an immune-adherence hemagglutination method. J Med Virol. 1978;2(3):215-23.

107. Kaye HS, Dowdle WR. Seroepidemiologic survey of coronavirus (strain 229E) infections in a population of children. Am J Epidemiol. 1975;101(3):238-44.

108. Gorse GJ, Patel GB, Vitale JN, O'Connor TZ. Prevalence of antibodies to four human coronaviruses in lower in nasal secretions than in serum. Clin Vaccine Immunol. 2010;17(12):1875-80.

109. Reed SE. The behavior of recent isolates of human respiratory coronavirus in vitro and in volunteers: evidence of heterogeneity among 229E-related strains. J Med Virol. 1984;13(2):179-92.

110. Callow KA. Effect of specific humoral immunity and some nonspecific factors on resistance of volunteers to respiratory coronavirus infection. J Hyg (Camb). 1985;95(1):173-80.

111. Callow KA, Parry HF, Sergeant M, Tyrrell DAJ. The time course of the immune response to experimental coronavirus infection of man. Epidemiol Infect. 1990;105(2):435-46.

112. Shirato K, Kawase M, Watanabe O, Hirokawa C, Matsuyama S, Nishimura $\mathrm{H}$, et al. Differences in neutralizing antigenicity between laboratory and clinical isolates of $\mathrm{HCoV}-229 \mathrm{E}$ isolated in Japan in 2004-2008 depend on the S1 region sequence of the spike protein. J Gen Virol. 2012;93(Pt 9):1908-17.

113. Okba NMA, Stalin Raj V, Widjaja I, GeurtsvanKessel CH, de Bruin E, Chandler FD, et al. Sensitive and specific detection of low-level antibody responses in mild Middle East respiratory syndrome coronavirus infections. Emerg Infect Dis. 2019;25(10): 1868-77.

114. Choe PG, Perera RAPM, Park WB, Song K-H, Bang JH, Kim ES, et al. MERS-CoV antibody responses 1 year after symptom onset, South Korea, 2015. Emerg Infect Dis. 2017;23(7):1079-84.

115. Payne DC, Iblan I, Rha B, Alqasrawi S, Haddadin A, Al Nsour M, et al. Persistence of antibodies against Middle East respiratory syndrome coronavirus. Emerg Infect Dis. 2016;22(10):1824-6.

116. Kim Y-S, Aigerim A, Park U, Kim Y, Rhee J-Y, Choi J-P, et al. Sequential emergence and wide spread of neutralization escape Middle East respiratory syndrome coronavirus mutants, South Korea, 2015. Emerg Infect Dis. 2019;25(6):1161-8.

117. Muth D, Corman VM, Meyer B, Assiri A, Al-Masri M, Farah M, et al. Infectious Middle East respiratory syndrome coronavirus excretion and serotype variability based on live virus isolates from patients in Saudi Arabia. J Clin Microbiol. 2015;53(9):2951-5.

118. Corman VM, Albarrak AM, Senosi Omrani A, Albarrak MM, Elamin Farah M, Almasri M, et al. Viral shedding and antibody response in 37 patients with Middle East respiratory syndrome coronavirus infection. Clin Infect Dis. 2016;62(4):477-83.

119. Nie Y, Wang G, Shi X, Zhang H, Qiu Y, He Z, et al. Neutralizing antibodies in patients with severe acute respiratory syndromeassociated coronavirus infection. J Infect Dis. 2004;190(6): 1119-26.

120. Wang S, Sakhatskyy P, Chou TH, Lu S. Assays for the assessment of neutralizing antibody activities against severe acute respiratory syndrome (SARS) associated coronavirus (SCV). J Immunol Methods. 2005;301(1-2):21-30.

121. Han DP, Kim HG, Kim YB, Poon LL, Cho MW. Development of a safe neutralization assay for SARS-CoV and characterization of S-glycoprotein. Virology. 2004;326(1):140-9.

122. Tripp RA, Haynes LM, Moore D, Anderson B, Tamin A, Harcourt $\mathrm{BH}$, et al. Monoclonal antibodies to SARS-associated coronavirus (SARS-CoV): identification of neutralizing and antibodies reactive to $\mathrm{S}, \mathrm{N}, \mathrm{M}$, and $\mathrm{E}$ viral proteins. J Virol Methods. 2005;128(1-2):21-8.

123. Subbarao K, McAuliffe J, Vogel L, Fahle G, Fischer S, Tatti K, et al. Prior infection and passive transfer of neutralizing antibody prevent replication of severe acute respiratory syndrome coronavirus in the respiratory tract of mice. J Virol. 2004;78(7):3572-7.

124. Roberts A, Thomas WD, Guarner J, Lamirande EW, Babcock GJ, Greenough TC, et al. Therapy with a severe acute respiratory syndrome-associated coronavirus-neutralizing human monoclonal antibody reduces disease severity and viral burden in Golden Syrian hamsters. J Infect Dis. 2006;193(5):685-92.

125. Zhao J, Wang W, Wang W, Zhao Z, Zhang Y, Lv P, et al. Comparison of immunoglobulin $G$ responses to the spike and nucleocapsid proteins of severe acute respiratory syndrome (SARS) coronavirus in patients with SARS. Clin Vaccine Immunol. 2007;14(7):839-46.

126. Elshabrawy HA, Coughlin MM, Baker SC, Prabhakar BS. Human monoclonal antibodies against highly conserved HR1 and HR2 domains of the SARS-CoV spike protein are more broadly neutralizing. PLoS One. 2012;7(11):e50366.

127. Chow PKH, Ooi E-E, Tan H-T, Ong K-W, Sil BK, Teo M, et al. Healthcare worker seroconversion in SARS outbreak. Emerg Infect Dis. 2004;10(2):249-50.

128. Wu HS, Chiu SC, Tseng TC, Lin SF, Lin JH, Hsu YH, et al. Serologic and molecular biologic methods for SARS-associated coronavirus infection, Taiwan. Emerg Infect Dis. 2004;10(2): 304-10.

129. Ho M-S, Chen W-J, Chen H-Y, Lin S-F, Wang M-C, Di J, et al. Neutralizing antibody response and SARS severity. Emerg Infect Dis. 2005;11(11):1730-7.

130. Liu W, Fontanet A, Zhang P-H, Zhan L, Xin Z-T, Baril L, et al. Two-year prospective study of the humoral immune response of patients with severe acute respiratory syndrome. J Infect Dis. 2006;193(6):792-5.

131. Shi Y, Wan Z, Li L, et al. Antibody responses against SARScoronavirus and its nucleocapsid in SARS patients. J Clin Virol. 2004;31(1):66-8.

132. Zhang J-S, Chen J-T, Liu X-Y, Zang Z-S, Gao H, Liu Y, et al. A serological survey on neutralizing antibody titer of SARS coronavirus convalescent sera. J Med Virol. 2005;77:147-50.

133. Cao W-C, Liu W, Zhang P-H, Zhang F, Richardus JH. Disappearance of antibodies to SARS-associated coronavirus after recovery. N Engl J Med. 2007;357(11):1162-3.

134. Zhang L, Zhang F, Yu W, He T, Yu J, Yi CE, et al. Antibody responses against SARS coronavirus are correlated with disease outcome of infected individuals. J Med Virol. 2006;78(1):1-8.

135. Yu S, Qiu M, Chen Z, Ye X, Gao Y, Wei A, et al. Retrospective serological investigation of severe acute respiratory syndrome coronavirus antibodies in recruits from mainland China. Clin Diagn Lab Immunol. 2005;12(4):552-4.

136. Mo H, Zeng G, Ren X, Li H, Ke C, Tan Y, et al. Longitudinal profile of antibodies against SARS-coronavirus in SARS patients and their clinical significance. Respirology. 2006;11(1):49-53.

137. Cao Z, Liu L, Du L, Zhang C, Jiang S, Li T, et al. Potent and persistent antibody responses against the receptor-binding domain of SARS-CoV spike protein in recovered patients. Virol J. 2010;7: 299. https://doi.org/10.1186/1743-422X-7-299.

138. Liu L, Xie J, Sun J, Han Y, Zhang C, Fan H, et al. Longitudinal profiles of immunoglobulin $\mathrm{G}$ antibodies against severe acute respiratory syndrome coronavirus components and neutralizing activities in recovered patients. Scand J Infect Dis. 2011;43(6-7): 515-21.

139. Guo J-P, Petric M, Campbell W, McGeer PL. SARS coronavirus peptides recognized by antibodies in the sera of convalescent cases. Virology. 2004;324(2):251-6. 
140. Berry JD, Jones S, Drebot MA, Andonov A, Sabara M, Yuan XY, et al. Development and characterization of neutralizing monoclonal antibody to the SARS-coronavirus. J Virol Methods. 2004;120(1):87-96.

141. Keng CT, Zhang A, Shen S, Lip KM, Fielding BC, Tan TH, et al. Amino acids 1055 to 1192 in the $\mathrm{S} 2$ region of severe acute respiratory syndrome coronavirus $\mathrm{S}$ protein induce neutralizing antibodies: implications for the development of vaccines and antiviral agents. J Virol. 2005;79(6):3289-96.

142. Qiu M, Shi Y, Guo Z, Chen Z, He R, Chen R, et al. Antibody responses to individual proteins of SARS coronavirus and their neutralization activities. Microbiol Infect. 2005;7(5-6):882-9.

143. Zhao G, Ni B, Jiang H, Luo D, Pacal M, Zhou L, et al. Inhibition of severe acute respiratory syndrome-associated coronavirus infection by equine neutralizing antibody in Golden Syrian hamsters. Viral Immunol. 2007;20(1):197-205.

144. Pang H, Liu Y, Han X, Xu Y, Jiang F, Wu D, et al. Protective humoral responses to severe acute respiratory syndromeassociated coronavirus: implications for the design of an effective protein-based vaccine. J Gen Virol. 2004;85(Pt 10):3109-13.

145. Buchholz UJ, Bukreyev A, Yang L, Lamirande EW, Murphy BR, Subbarao K, et al. Contributions of the structural proteins of severe acute respiratory syndrome coronavirus to protective immunity. PNAS. 2004;101(26):9804-9.

146. Lee JS, Poo H, Han DP, Hong SP, Kim K, Cho MW, et al. Mucosal immunization with surface-displayed severe acute respiratory syndrome coronavirus spike protein on Lactobacillus casei induces neutralizing antibodies in mice. J Virol. 2006;880(8): 4079-87.

147. Rani M, Bolles M, Donaldson EF, Van Blarcom T, Baric R, Iverson $\mathrm{B}$, et al. Increased antibody affinity confers broad in vitro protection against escape mutants of severe acute respiratory syndrome coronavirus. J Virol. 2012;86(17):9113-23.

148. Bisht H, Roberts A, Vogel L, Bukreyev A, Collins PL, Murphy $\mathrm{BR}$, et al. Severe acute respiratory syndrome coronavirus spike protein expressed by attenuated vaccinia virus protectively immunizes mice. Proc Natl Acad Sci U S A. 2004;101(17):6641-6.

149. Chen Z, Zhang L, Qin C, Ba L, Yi CE, Zhang F, et al. Recombinant modified vaccinia virus Ankara expressing the spike glycoprotein of severe acute respiratory syndrome coronavirus induces protective neutralizing antibodies primarily targeting the receptor binding region. J Virol. 2005;79(5):267888 .

150. Weingartl H, Czub M, Czub S, Neufeld J, Marszal P, Gren J, et al. Immunization with modified vaccinia virus Ankara-based recombinant vaccine against severe acute respiratory syndrome is associated with enhanced hepatitis in ferrets. J Virol. 2004;78(22): 12672-6.

151. Czub M, Weingartl H, Czub S, He R, Cao J. Evaluation of modified vaccinia Ankara based recombinant SARS vaccine in ferrets. Vaccine. 2005;23(17-18):2273-9.

152. Chu YK, Ali GD, Jia F, Li Q, Kelvin D, Couch RC, et al. The SARS-CoV ferret model in an infection-challenge study. Virology. 2008;374(1):151-63.

153. Deming D, Sheahan T, Heise M, Yount B, Davis N, Sims A, et al. Vaccine efficacy in senescent mice challenged with recombinant SARS-CoV bearing epidemic and zoonotic spike variants. PLoS Med. 2006;3(12):e525.

154. Ba L, Yi CE, Zhang L, Ho DD, Chen Z. Heterologous MVA-S prime Ad5-S boost regimen induces high and persistent levels of neutralizing antibody responses against SARS coronavirus. Appl Microbiol Biotechnol. 2007;76(5):1131-6.

155. Qu D, Zheng B, Yao X, Guan Y, Yuan Z-H, Zhong N-S, et al. Intranasal immunization with inactivated SARS-CoV (SARSassociated coronavirus) induced local and serum antibodies in mice. Vaccine. 2005;23(7):924-31.
156. Gai W, Zou W, Lei L, Luo J, Tu H, Zhang Y, et al. Effects of different immunization protocols and adjuvant on antibody responses to inactivated SARS-CoV vaccine. Viral Immunol. 2008;21(1):27-37.

157. See RH, Zakhartchouk AN, Petric M, Lawrence DJ, Mok CP, Hogan RJ, et al. Comparative evaluation of two severe acute respiratory syndrome (SARS) vaccine candidates in mice challenged with SARS coronavirus. J Gen Virol. 2006;87(Pt 3):64150 .

158. Zhou J, Wang W, Zhong Q, Hou W, Yang Z, Xiao S-Y, et al. Immunogenicity, safety, and protective efficacy of an inactivated SARS-associated coronavirus vaccine in rhesus monkeys. Vaccine. 2005;23:3202-9.

159. Lamirande EW, DeDiego ML, Roberts A, Jackson JP, Alvarez E, Sheahan T, et al. A live attenuated severe acute respiratory syndrome coronavirus is immunogenic and efficacious in Golder Syrian hamsters. J Virol. 2008;82(15):7721-4.

160. Wang Q, Zhang L, Kuwahara K, Li L, Liu Z, Li T, et al. Immunodominant SARS coronavirus epitopes in humans elicited both enhancing and neutralizing effects on infection in nonhuman primates. ACS Infect Dis. 2016;2(5):361-76.

161. Kam YW, Kien F, Roberts A, Cheung YC, Lamirande EW, Vogel $\mathrm{L}$, et al. Antibodies against trimeric $\mathrm{S}$ glycoprotein protect hamsters against SARS-CoV challenge despite their capacity to mediate $\mathrm{Fc} \gamma \mathrm{RII}-\mathrm{dependent}$ entry into B cells in vitro. Vaccine. 2007;25(4):729-40.

162. Liu L, To KK-W, Chan K-H, Wong Y-C, Zhou R, Kwan K-Y, et al. High neutralizing antibody titer in intensive care unit patients with COVID-19. Emerg Infect Dis. 2020;3:1-30. https://doi.org/ 10.1080/22221751.2020.1791738.

163. Nielsen SCA, Yang F, Hoh RA, Jackson KJL, Roeltgen K, Lee J$\mathrm{Y}$, et al. Human B cell clonal expansion and convergent antibody responses to SARS-CoV-2. Res Sq. 2020;rs-27220. https://doi. org/10.21203/rs.3.rs-27220/v1.

164. Lv H, Wu NC, Tsang OT-Y, Yuan M, Perera RAPM, Leung WS, et al. Cross-reactive antibody response between SARS-CoV-2 and SARS-CoV infections. Cell Rep. 2020;18:107725. https://doi.org/ 10.1016/j.celrep.2020.107725.

165. Dong S, Sun J, Mao Z, Wang L, Lu YL, Li J. A guideline for homology modeling of the proteins from newly discovered betacoronavirus, 2019 novel coronavirus (2019-nCoV). J Med Virol. 2020. https://doi.org/10.1002/jmv.25768.

166. Kim YI, Kim SG, Kim SM, Kim EH, Park SJ, Yu KM, et al. Infection and rapid transmission of SARS-CoV-2 in ferrets. Cell Host Microbe. 2020. https://doi.org/10.1016/j.chom.2020.03.023.

167. Shan C, Yao Y-F, Yang X-L, Zhou Y-W, Gao G, Peng Y, et al. Infection with novel coronavirus (SARS-CoV-2) causes pneumonia in rhesus macaques. Cell Res. 2020. https://doi.org/10.1038/ s41422-020-0364-Z

168. Zost SJ, Gilchuk P, Case JB, Binshtein E, Chen RE, Nkolola JP, et al. Potently neutralizing and protective human antibodies against SARS-CoV-2. Nature. 2020. https://doi.org/10.1038/ s41586-020-2548-6.

169. Cao Y, Su B, Guo X, Sun W, Deng Y, Bao L, et al. Potent neutralizing antibodies against SARS-CoV-2 identified by highthroughput single-cell sequencing of convalescent patients' B cells. Cell. 2020;182(1):73-84.e16.

170. Abolghasemi H, Eshghi P, Cheraghali AM, Fooladi AAI, Moghaddam FB, Imanizadeh S, et al. Clinical efficacy and convalescent plasma for treatment of COVID-19 infections: results of a multicenter clinical study. Transfus Apher Sci. 2020;15:102875. https://doi.org/10.1016/j.transci.2020.102875.

171. Liu L, Wang P, Nair MS, Yu J, Rapp M, Wang Q, et al. Potent neutralizing antibodies directed to multiple epitopes on SARSCoV-2 spike. Nature. 2020. https://doi.org/10.1038/s41586-0202571-7. 
172. Juno JA, Tan H-X, Lee WS, Reynaldi A, Kelly HG, Wragg K, et al. Humoral and cellular and circulating follicular helper T cell responses in recovered patients with COVID-19. Nat Med. 2020. https://doi.org/10.1038/s41591-020-0995-0.

173. Ni L, Ye F, Cheng ML, Feng Y, Deng YQ, Zhao H, et al. Detection of SARS-CoV-2-specific humoral and cellular immunity in COVID-19 convalescent individuals. Immunity. 2020. https://doi.org/10.1016/j.immunol.2020.04.023.

174. Wan J, Xing S, Ding L, Wang Y, Gu C, Wu Y, et al. Human-IgGneutralizing monoclonal antibodies block the SARS-CoV-2 infection. Cell Rep. 2020;3:107918. https://doi.org/10.1016/j.celrep. 2020.107918.

175. Le Bert N, Tan AT, Kunasegaran K, Tham CYL, Hafezi M, Chia A, et al. SARS-CoV-2-specific $\mathrm{T}$ cell immunity in cases of COVID-19 and SARS, and uninfected controls. Nature. 2020. https://doi.org/10.1038/s41586-020-2550-z.

176. Weisberg SP, Connors T, Zhu Y, Baldwin M, Lin W-H, Wontakal $\mathrm{S}$, et al. Antibody response to SARS-CoV-2 are distinct in children with MIS-C compared to adults with COVID-19. medRxiv. 2020;2020.07.12.20151068. https://doi.org/10.1101/2020.07.12. 20151068 .

177. Case JB, Rothlauf PW, Chen RE, Kafai NM, Fox JM, Smith BK, et al. Replication-competent vesicular stomatitis virus vaccine vector protects against SARS-CoV-2-mediated pathogenesis in mice. Cell Host Microbe. 2020;28(3):465-474.

178. Arvin A, Fink K, Schmid MA, Cathcart A, Spreafico R, HavenarDaughton C, et al. A perspective on potential antibody-dependent enhancement of SARS-CoV-2. Nature. 2020. https://doi.org/10. 1038/s41586-020-2538.

179. Cimolai N. A minimalist strategy towards temporarily defining protection for COVID-19. SN Compr Clin Med. 2020;19:1-8. https://doi.org/10.1007/s42399-020-00533-4.

Publisher's Note Springer Nature remains neutral with regard to jurisdictional claims in published maps and institutional affiliations. 